D-18計算機対話型作業における人間特性の研究

(その1) 測定システムの構成

○吉岡真、野吕影勇、山本栄(産業医科大学)

小松原明哲、横满克己(早稻田大学理工学部)

1、概 要

林喜男 (度應義整大学理工学部)

計算㮦対話型作業における人間の特性についての研究を行なった。被涘者にVDT(Visual Display Terminal）を用いた单語楧索作業を2時間行なわせ、この作業による人間の生理的及び心理的根能の

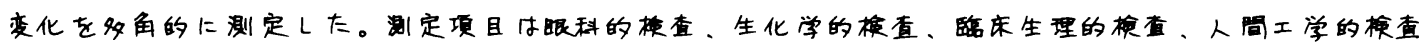
など多項目に渡る。本榶では、これらの测定を同時、亚行的に行なうための测定システムの概要を報 告する。

2. 目 的

本实駸の目的は大きく次のろつにれかれる。

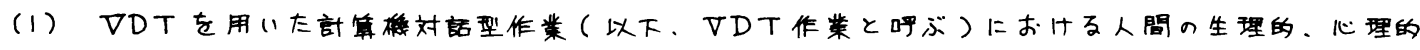

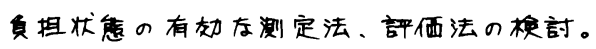

(2) VDT作業への各年令属の透応性の模討。

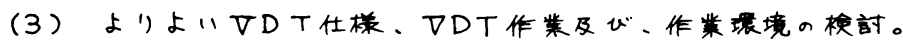

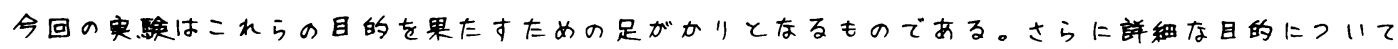
は本稿に続く各報告を参照のこと。

3. 实 駛概要

$(3-1)$ 作業内容

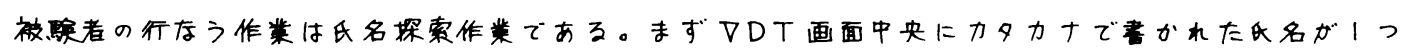
提示され(これをターゲットと呼ぶ)、次にターゲットを何個か含む80名の氏名のリストが提示士れ る。被糇者はこのリストの中よりターゲットを見つけ出し、その度にボタンを坜す。は画面について の作業終了時に画面变塔ボタンを押し、これにより新しいターゲットの提示があり新しい作葉に矽る。

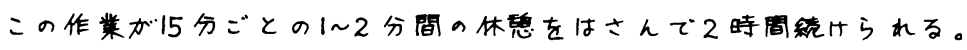

\title{
(3-2) 作䄅の種類
}

VDTを用いた作業では文字の大きさについては大小2通り、1作業時間については30秒の時䦌

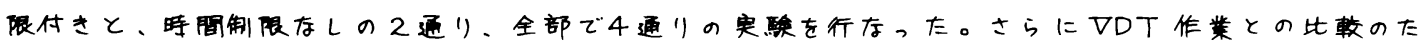

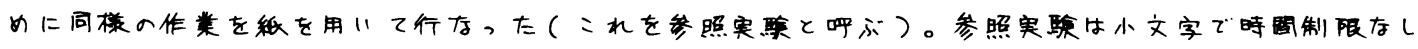
のリ通りのみである。

(3-3) 被誤者

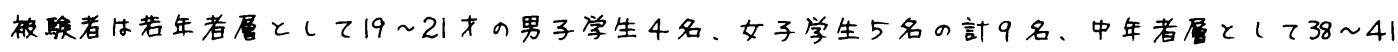

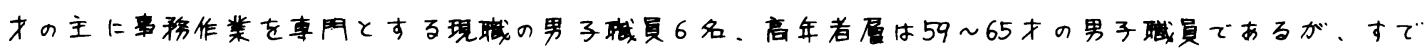
に退煘した者も含まれている。

\section{(3-4)，VDT作䅈使用機材}

VDTとしてはRadio Shack のキャラフタ・ディスプレイ(グリーン・モニタ)を用い、画面提示 のコントロールはRadio Shack の TRS - 80 model I マイクロコンピータ.システムを使用した。

4. 测 定項 目

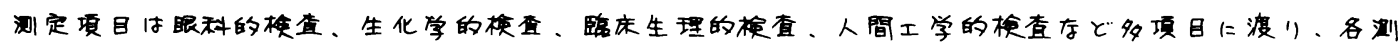


定は所定の時刻に行ないれる。表1に各測定項目とその测定時刻を、园1及び四2に测定システムの

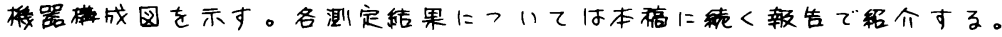

\section{表 1。VDT作業実験测定検査項目一䜿表}

\begin{tabular}{|c|c|c|c|c|c|c|c|}
\hline & 測定 検 査 項 目 & 事前検查 & 起床時 & 作業直前 & \begin{tabular}{|l|l|l|} 
作業中 \\
$(2$ 間)
\end{tabular} & 作業直後 & 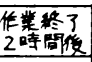 \\
\hline 眼科的 & 視力、眼圧、屈折異常 & 0 & & & & & \\
\hline 搔否垻目 & 眼の既応症の確認（男膜、結膜、眼底模直など） & O & & & & & \\
\hline & 言周饰䋇能（毛栚体、睡孔） & & & $\bigcirc$ & & 0 & O \\
\hline & 血装検直(アルテデステロソ、アドレナリソ、ルルアドレナリン） & & & O & & O & O \\
\hline 生化学的 & 血清検查 $(C P K)$ & & & O & & O & O \\
\hline 娭査境目 & 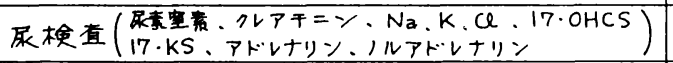 & & $\bigcirc$ & O & & O & O \\
\hline & 汗検査 $\left(\mathrm{al}^{-}\right)$ & & & O & O & O & O \\
\hline & 脑波 EEG & & & & O & & \\
\hline & 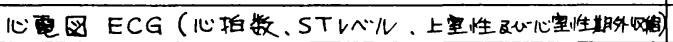 & & & O & 0 & O & \\
\hline 医㕅生理的 & 眼夜四 EOG（探案方法、まばたき回数） & & & & O & & \\
\hline 検查項目 & 呼収曲緣（呼収数、呼収深度） & & & & O & & \\
\hline & 春髄反射波 H波 & & & O & & O & O \\
\hline & 血圧 & & & 0 & O & 0 & O \\
\hline & フリッカー & & & $\bigcirc$ & & 0 & $\bigcirc$ \\
\hline 人間工学的 & 反元時間 & & & O & & $\bigcirc$ & $\bigcirc$ \\
\hline 及ル゙ & 作業観蕗 1 （副次動作、表情など） & & & & 0 & & \\
\hline その他の & 作粪覩察2（まはたき回数、眼瞼の状能など） & & & & 0 & & \\
\hline & パフォーマンス（全作業量、1作菜時閻、ミス事など） & & & & O & & \\
\hline & 心理テスト（MAS 不安傾向の有無） & 0 & & & & & \\
\hline & アンイート謂查 & & & 0 & & 0 & \\
\hline
\end{tabular}

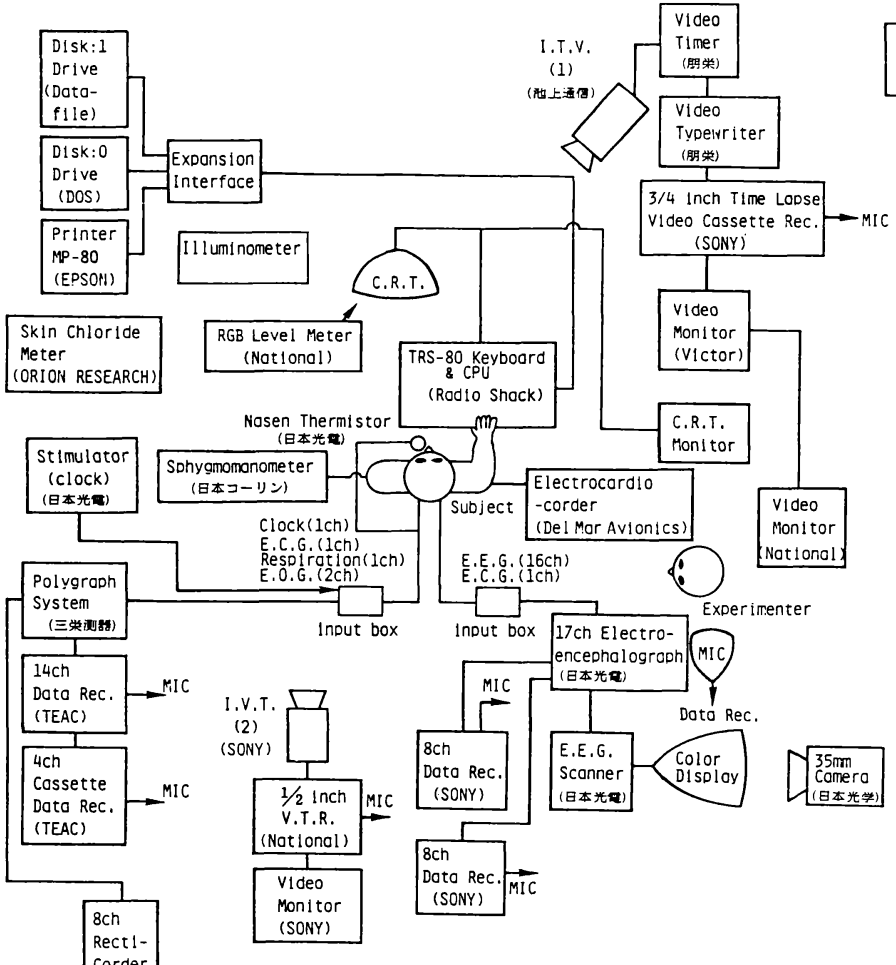

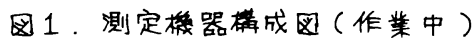

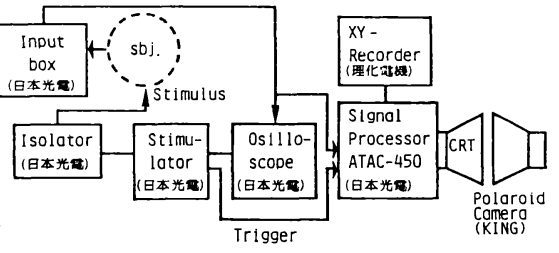

(a) 春咀反射波( $\mathrm{H}$ 波)

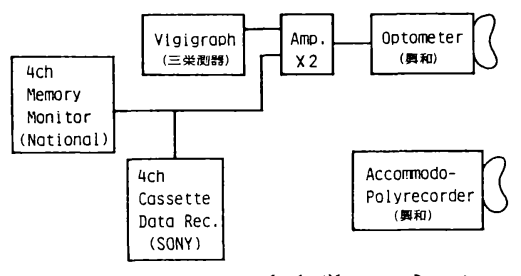

(b) 謂施機能(毛梾体、睡孔)

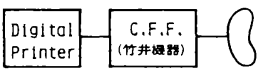

(c) フリッカ-(CFF)

\begin{tabular}{|l|l|}
\hline Whole Body \\
Reoction \\
Meter \\
(TT井
\end{tabular}

(d) 反応時問

図2. 测定機器楧成图(作業前後) 